\title{
Probabilistic landslide hazards and risk mapping on Penang Island, Malaysia
}

\author{
SARo LeE ${ }^{1}$ and Biswajeet Pradhan ${ }^{2, *}$ \\ ${ }^{1}$ Geoscience Information Center, Korea Institute of Geoscience and Mineral Resources (KIGAM) 30, \\ Kajung-Dong, Yusung-Gu, Daejeon, Korea. \\ e-mail: leesaro@kigam.re.kr \\ ${ }^{2}$ Cilix Corporation, Lot L4-I-6, Level 4, Enterprise 4, Technology Park Malaysia, Bukit Jalil Highway, \\ Bukit Jalil, 57000, Kuala Lumpur, Malaysia. \\ *e-mail: biswajeet@mailcity.com
}

\begin{abstract}
This paper deals with landslide hazards and risk analysis of Penang Island, Malaysia using Geographic Information System (GIS) and remote sensing data. Landslide locations in the study area were identified from interpretations of aerial photographs and field surveys. Topographical/ geological data and satellite images were collected and processed using GIS and image processing tools. There are ten landslide inducing parameters which are considered for landslide hazard analysis. These parameters are topographic slope, aspect, curvature and distance from drainage, all derived from the topographic database; geology and distance from lineament, derived from the geologic database; landuse from Landsat satellite images; soil from the soil database; precipitation amount, derived from the rainfall database; and the vegetation index value from SPOT satellite images. Landslide susceptibility was analyzed using landslide-occurrence factors employing the probability-frequency ratio model. The results of the analysis were verified using the landslide location data and compared with the probabilistic model. The accuracy observed was $80.03 \%$. The qualitative landslide hazard analysis was carried out using the frequency ratio model through the map overlay analysis in GIS environment. The accuracy of hazard map was $86.41 \%$. Further, risk analysis was done by studying the landslide hazard map and damageable objects at risk. This information could be used to estimate the risk to population, property and existing infrastructure like transportation network.
\end{abstract}

\section{Introduction}

Landslide is one of the many natural processes that shape the surface of the Earth. It is only when landslides threaten mankind that they represent a hazard. Recently there have been many occurrences of landslides in Malaysia. Most of these have occurred on cut slopes or on embankments alongside roads and highways in mountainous areas. Some of these landslides occurred near high-rise apartments and in residential areas. A few major and catastrophic landslides have occurred within the last decade. Landslide risk analysis, like many other forms of risk management of either natural or civil engineering hazards, is a relatively new discipline. Earlier attempts to reduce landslide risk is largely a history of management of landslide terrain, construction of protective structures or monitoring and warning systems, or the ever-increasing sophisticated methods for mapping and delineating areas prone to landslides (Dai et al 2002). In Malaysia, little attention has been paid to the people who live within landslide-prone areas. Unfortunately not much database is available about them and the measures taken to avoid loss. In this paper, efforts have been made to study landslide hazards

Keywords. Landslide; frequency ratio; landslide hazard; risk analysis; geographic information system; remote sensing. 
and the risk areas of Penang Island. Through a scientific analysis of landslide-inducing parameters, it is possible to assess and predict landslidehazard areas, and decrease landslide damage using effective emergency preparedness plans. To achieve this, landslide hazard and risk analysis techniques have been applied, and verified in the study area. In addition, landslide-related factors were also assessed. Geographic Information System (GIS) software, ArcView 3.2, and ArcInfo 8.1 NT versions were used as the basic analysis tools for spatial management and data manipulation.

There are three steps in landslide analysis: susceptibility, hazard, and risk (Einstein 1988). In this study, susceptibility, hazard and risk analysis have been performed. However, possibility analysis could not be performed due to lack of data. It is possible to predict a landslide when combined with a hydrological model which can lead to an accurate analysis. Landslide risk can also be calculated if one takes into account the potential vulnerability of houses and buildings.

Risk analysis is a valid technique if and only if it fulfills a series of appropriate criteria. It should state the probability as well as the expected impact, and the latter should be expressed in relation to the size of the population at risk. Varne (1984); Fell (1994); Whitman (1984); and Christian et al (1992) have performed studies related to risk analysis. There have been many studies carried out on landslide hazard evaluation using GIS. Guzzetti et al (1999) have summarized many landslide hazard evaluation studies. Many of the recent studies have applied probabilistic models (Rowbotham and Dudycha 1998; Jibson et al 2000; Luzi et al 2000; Parise and Jibson 2000; Rautelal and Lakheraza 2000; Baeza and Corominas 2001; Lee and Min 2001; Temesgen et al 2001; Clerici et al 2002; Donati and Turrini 2002; Lee et al 2002a, 2002b; Rece and Capolongo 2002; Zhou et al 2002; Lee and Choi 2003c). The logistic regression model has also been applied to landslide hazard mapping (Atkinson and Massari 1998; Dai et al 2001; Dai and Lee 2002; Ohlmacher and Davis 2003). Various other studies including the geotechnical model and the safety factor model indicate the landslide hazard and risk analysis (Gokceoglu et al 2000; Romeo 2000; Carro et al 2003; Shou and Wang 2003; Zhou et al 2003). Recently, landslide hazard evaluation using fuzzy logic, and artificial neural network models have been mentioned in the various literature (Ercanoglu and Gokceoglu 2002; Pistocchi 2000; Lee et al 2003a, 2003b, 2004a, 2004b).

In the present paper, landslide hazard assessment has been performed using the landslideinducing parameters based on the frequency ratio model. Landslide-inducing parameters have been

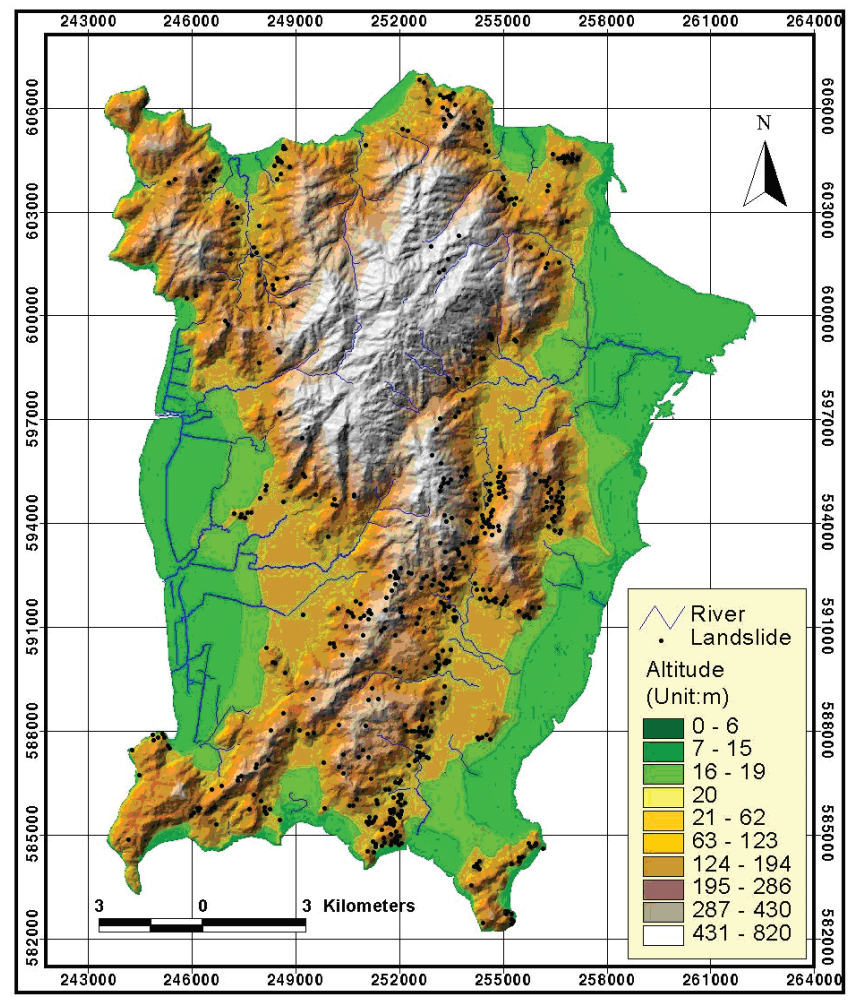

Figure 1. Hill shaded map showing the location of landslides.

collected and transformed into a spatial database. Frequency ratio values for each of these parameters have been computed using GIS tools. Accuracy assessment of the hazard map was performed using a newly developed program in Macro objects. A key assumption while using the probabilityfrequency ratio approach is that the occurrence possibility of landslides is comparable to the actual frequency of landslides. Landslide-occurrence areas were detected on Penang Island by interpreting aerial photographs and field surveys. Then, a landslide location map was generated from aerial photographs, in combination with the GIS data, and was used to evaluate the frequency and distribution of shallow landslides in the study area.

\section{Study area and data}

Penang Island, which has suffered much landslide damage following heavy rains, was selected as a suitable pilot area to evaluate landslide risk analysis (figure 1). Penang is one of the 13 states of the Federal territory of Malaysia and is located on the northwest coast of the Malaysia peninsula. It is bound to the north and east by the state of Kedah, to the south by the state of Perak, and to the west by the Straits of Malacca and Sumatra (Indonesia). Penang consists of the island of Penang, and a coastal strip on the mainland, 
Table 1. Data layers of study area.

\begin{tabular}{llll}
\hline Classification & \multicolumn{1}{c}{ Sub-classification } & \multicolumn{1}{c}{ GIS data type } & Scale \\
\hline Geological Hazard & Landslide & Point coverage & $1: 25,000$ \\
Base Map & Topography & Line, point and polygon coverage & $1: 25,000$ \\
& Geology & Polygon coverage & $1: 63,300$ \\
& Landuse & GRID & $30 \mathrm{~m} \times 30 \mathrm{~m}$ \\
& Vegetation index (NDVI) & GRID & $10 \mathrm{~m} \times 10 \mathrm{~m}$ \\
& Lineament & Line coverage & $1: 25,000$ \\
& Soil & GRID & $10 \mathrm{~m} \times 10 \mathrm{~m}$ \\
& Disaster Support Center & Point coverage & $1: 25,000$ \\
& Transportation network & Line coverage & $1: 25,000$ \\
& Population & Polygon & $1: 25,000$
\end{tabular}

known as Province Wellesley. The island covers an area of $285 \mathrm{~km}^{2}$, and is separated from the mainland by a channel. The study area is located approximately between latitudes $5^{\circ} 15^{\prime} \mathrm{N}$ to $5^{\circ} 30^{\prime} \mathrm{N}$ and longitudes $100^{\circ} 10^{\prime} \mathrm{E}$ to $100^{\circ} 20^{\prime} \mathrm{E}$. The landuse in the study area is mainly peat swamp forest, plantation forest, inland forest, scrub, grassland and ex-mining area. The slope of the area ranges from 25 degrees to as much as 87 degrees. The relief of the study area varies between 0 and 420 meters above mean sea level. Based on Malaysian Meteorological Department data, the temperature of the northern part of Penang ranges between $29^{\circ} \mathrm{C}$ and $32^{\circ} \mathrm{C}$ and the mean relative humidity between $65 \%$ and $70 \%$. The highest temperature is during April to June while the relative humidity is lowest in June, July and September. The rainfall of about $58.6 \mathrm{~mm}$ to $240 \mathrm{~mm}$ per month is recorded in the study area (at the Bayan Lepas weather station provided by the Malaysian Meteorological Services Department).

Accurate detection of the landslide location is very important for probabilistic landslide hazard analysis. Remote sensing methods, using aerial photographs and satellite images are employed to obtain significant and cost-effective information on landslides. In this study, 1:10,000-1:50,000-scale aerial photographs were used to detect the landslide locations. These photographs were taken during 1981-2000. Landslide locations were detected by aerial photo interpretation and further verified by fieldwork. These landslides can be seen in aerial photographs by interpreting breaks in the forest canopy, bare soil, and other typical geomorphic characteristics of landslide scars. A total of 463 landslides were mapped within $285 \mathrm{~km}^{2}$ to assemble a database to assess the surface area and the number of landslides in the study area.
Identification and mapping of a suitable set of instability factors related to the slope failures require a priori knowledge of the main causes of landslides (Guzzetti et al 1999). These instability factors include surface and bedrock lithology and structure, seismicity, slope steepness and morphology, stream evolution, groundwater conditions, climate, vegetation cover, landuse, and human activity. The availability of thematic data varies widely, depending on the type, scale, and method of data acquisition. To apply the probabilistic model, a spatial database that considers landslide-related factors was designed and constructed. These data are available in Malaysia either as paper or as digital maps. The spatial database constructed is listed in table 1.

There were ten landslide-inducing factors considered in calculating the probability. These factors were transformed into a vector-type spatial database using the GIS. For the DEM creation, 10-meter interval contours and survey base points showing the elevation values were extracted from the 1:25,000-scale topographic maps. Using this DEM, slope angle, slope aspect, and slope curvature were calculated. In addition, the distance from drainage was calculated using the topographic database. The drainage buffer was calculated at 100-meter intervals and classified into 10 equal area classes. The lithology map is prepared from a 1:63,300-scale geological map and the distance from lineament is calculated based on the Euclidean distance method in ArcView. The lineament buffer was calculated in 100-meter intervals and classified into 10 equal area classes. Landuse map was prepared using Landsat TM image $(30 \mathrm{~m}$ spatial resolution) using an unsupervised classification method and field survey. There were 11 landuse classes identified, such as urban, water, forest, agriculture, and barren area. Finally, the Normalized 
Difference Vegetation Index (NDVI) map was generated from SPOT 5 (2.5 m spatial resolution) satellite images. The NDVI value was calculated using the formula NDVI $=(I R-R) /(I R+R)$, where $I R$ is the energy reflected in the infrared portion of the electromagnetic spectrum, and $R$ is the energy reflected in the red portion of the electromagnetic spectrum. The NDVI is useful in delineating vegetation.

\section{Frequency ratio model and relationship between landslides and landslide-related factors}

In general, to predict landslides, it is necessary to assume that landslide occurrence is determined by landslide-related factors, and that future landslides will occur under the same conditions as past landslides. Using this assumption, the relationship between landslides occurring in an area and the landslide-related factors can be distinguished from the relationship between landslides not occurring in an area and the landslide-related factors. We used the frequency ratio to represent the distinction quantitatively. The frequency ratio is the ratio of the area where landslides occurred to the total study area, and also, is the ratio of the probabilities of a landslide occurrence to a non-occurrence for a given factor's attribute. Therefore, the greater the ratio above unity, the stronger the relationship between landslide occurrence and the given factor's attribute, and the lower the ratio below unity, the lesser the relationship between landslide occurrence and the given factor's attribute. To calculate the frequency ratio, a table (table 2) was constructed for each landslide-related factor. Then, the ratio of landslide occurrence and non-occurrence was calculated for each range or type of factor, and the area ratio for each range or type of factor to the total area was calculated. Finally, the frequency ratio for each range or type of factor was calculated by dividing the landslide-occurrence ratio by the area ratio.

The factors chosen such as slope, aspect, curvature, distance from drainage, geology, distance from lineament, landuse, soil, precipitation, and vegetation index were evaluated using the frequency ratio model to determine the level of correlation between the location of the landslides in the study area and these factors. Probabilistic approaches are based on the observed relationship between each factor and the distribution of landslides.

The relationship between landslide occurrence and slope (table 2) shows that steeper slopes have greater landslide probabilities. Below a slope of $15^{\circ}$, the frequency ratio was 0.20 , which indicates a very low probability of landslide occurrence. For slopes above $16^{\circ}$, the ratio was $>1$, which indicates a high probability of landslide occurrence. As the slope angle increases, then the shear stress in the soil or other unconsolidated material generally increases. Gentle slopes are expected to have a low frequency of landslides because of the generally lower shear stresses associated with low gradients. Steep natural slopes resulting from outcropping bedrock, however, may not be susceptible to shallow landslides. In the case of the aspect (table 2), landslides were most abundant on south-facing and northeast-facing slopes. The frequency of landslides was lowest on east-facing, west-facing, and northwest-facing slopes, except in flat areas. The curvature values represent the morphology of the topography. A positive curvature indicates that the surface is upwardly convex at that pixel. A negative curvature indicates that the surface is upwardly concave at that pixel. A value of zero indicates that the surface is flat. As shown in table 2, the more positive or negative the curvature value the higher the probability of landslide occurrence. Flat areas had a low frequency ratio of 0.20 . Concave areas had a frequency ratio of 0.41 . The reason for this is that following heavy rainfall, a concave slope contains more water and retains this water for a longer period which could lead to failure of slope triggering landslide. Convex areas had a frequency ratio of 3.07. The reason for this is that a convex rounded hilltop slope could be exposed to repeated dilation and contraction of loose debris on an inclined surface that might induce a creeping or mudslide due to heavy rainfall. Analysis was carried out to assess the influence of drainage lines on landslide occurrence. For this purpose, the proximity of landslide to drainage lines was identified by buffering (table 2). It can be seen that as the distance from a drainage line increases, the landslide frequency generally decreases. At a distance of $<250 \mathrm{~m}$, the ratio was $>1$, indicating a high probability of landslide occurrence, and at distances $>251 \mathrm{~m}$, the ratio was $<1$, indicating very less probability. This can be attributed to the fact that terrain modification caused by gully erosion may influence the initiation of landslides. However, at a distance of $<50 \mathrm{~m}$, the frequency ratio is 0.81 which is due to the less number of previously-occurred landslides.

For geological factors (table 2), it was found that in the case of the lithology, the frequency ratio was higher (1.3) in igneous rock areas, and was lower (0.02) in alluvium areas. In the case of the distance from lineament, the closer the distance was to the lineament, the greater was the landslide-occurrence probability. For distances of $<1000 \mathrm{~m}$, the ratio was $>1$, indicating a high 
Table 2. Frequency ratio of landslide occurrences.

\begin{tabular}{|c|c|c|c|c|c|c|}
\hline \multirow[b]{2}{*}{ Factor } & \multirow[b]{2}{*}{ Class } & \multicolumn{2}{|c|}{$\begin{array}{l}\text { Total number of } \\
\text { pixels }\end{array}$} & \multicolumn{2}{|c|}{$\begin{array}{l}\text { Landslide occurrence } \\
\text { pixels }\end{array}$} & \multirow{2}{*}{$\begin{array}{l}\text { Frequency } \\
\text { ratio }\end{array}$} \\
\hline & & Number $^{\mathrm{a}}$ & $\%$ & Number $^{\mathrm{b}}$ & $\%$ & \\
\hline \multirow[t]{4}{*}{ Slope } & $0 \sim 15$ degree & 1709800 & 57.87 & 53 & 11.45 & 0.20 \\
\hline & $16 \sim 25$ degree & 765189 & 25.90 & 152 & 32.83 & 1.27 \\
\hline & $26 \sim 35$ degree & 360229 & 12.19 & 157 & 33.91 & 2.78 \\
\hline & $>35$ degree & 119564 & 4.05 & 101 & 21.81 & 5.39 \\
\hline \multirow[t]{9}{*}{ Aspect } & Flat & 1199400 & 40.59 & 13 & 2.80 & 0.07 \\
\hline & North & 206629 & 6.99 & 41 & 8.85 & 1.27 \\
\hline & Northeast & 207860 & 7.03 & 51 & 11.01 & 1.57 \\
\hline & East & 228674 & 7.74 & 60 & 12.95 & 1.67 \\
\hline & Southeast & 236988 & 8.02 & 82 & 17.71 & 2.21 \\
\hline & South & 205108 & 6.94 & 58 & 12.53 & 1.80 \\
\hline & Southwest & 206970 & 7.01 & 52 & 11.23 & 1.60 \\
\hline & West & 228117 & 7.72 & 54 & 11.66 & 1.51 \\
\hline & Northwest & 235036 & 7.95 & 52 & 11.23 & 1.41 \\
\hline \multirow[t]{3}{*}{ Curvature } & Concave & 770757 & 26.09 & 50 & 10.80 & 0.41 \\
\hline & Flat & 1419529 & 48.04 & 45 & 9.72 & 0.20 \\
\hline & Convex & 764496 & 25.87 & 368 & 79.48 & 3.07 \\
\hline \multirow{7}{*}{$\begin{array}{l}\text { Distance from } \\
\text { drainage }\end{array}$} & $0 \sim 50 \mathrm{~m}$ & 919481 & 31.11 & 117 & 25.26 & 0.81 \\
\hline & $51 \sim 100 \mathrm{~m}$ & 648322 & 21.94 & 114 & 24.62 & 1.12 \\
\hline & $101 \sim 150 \mathrm{~m}$ & 453610 & 15.35 & 80 & 17.27 & 1.13 \\
\hline & $151 \sim 200 \mathrm{~m}$ & 299500 & 10.13 & 53 & 11.44 & 1.13 \\
\hline & $201 \sim-250 \mathrm{~m}$ & 189645 & 6.41 & 41 & 8.85 & 1.38 \\
\hline & $251 \sim 300 \mathrm{~m}$ & 120824 & 4.08 & 14 & 3.02 & 0.74 \\
\hline & $>301 \mathrm{~m}$ & 323400 & 10.94 & 44 & 9.5 & 0.87 \\
\hline \multirow[t]{3}{*}{ Geology } & Micro granite & 43801 & 1.52 & 7 & 1.512 & 0.98 \\
\hline & Alluvium & 668834 & 23.34 & 2 & 0.432 & 0.01 \\
\hline & Granite & 2151905 & 75.12 & 454 & 98.056 & 1.305 \\
\hline \multirow[t]{8}{*}{ Soil } & $\begin{array}{l}\text { Rengam-bukit } \\
\text { temiang association }\end{array}$ & 289450 & 10.03 & 96 & 20.73 & 2.07 \\
\hline & $\begin{array}{l}\text { Selangor-kangkong } \\
\text { association }\end{array}$ & 34197 & 1.18 & 0 & 0.00 & 0.00 \\
\hline & $\begin{array}{l}\text { Local alluvium- } \\
\text { colluvium association }\end{array}$ & 373655 & 12.94 & 13 & 2.81 & 0.22 \\
\hline & Serong series & 80436 & 2.79 & 0 & 0.00 & 0.00 \\
\hline & Seep land & 1506818 & 52.20 & 341 & 73.65 & 1.41 \\
\hline & $\begin{array}{l}\text { Kuala kedah- } \\
\text { permatang association }\end{array}$ & 187057 & 6.48 & 0 & 0.00 & 0.00 \\
\hline & Urban land & 413813 & 14.33 & 13 & 2.81 & 0.20 \\
\hline & Rengam series & 1329 & 0.05 & 0 & 0.00 & 0.00 \\
\hline \multirow{6}{*}{$\begin{array}{l}\text { Distance from } \\
\text { lineament }\end{array}$} & $0 \sim 200 \mathrm{~m}$ & 341528 & 11.55 & 62 & 13.39 & 1.16 \\
\hline & $201 \sim 500 \mathrm{~m}$ & 490760 & 16.60 & 117 & 25.26 & 1.52 \\
\hline & $501 \sim 1000 \mathrm{~m}$ & 667520 & 22.59 & 118 & 25.48 & 1.13 \\
\hline & $1001 \sim 2000 \mathrm{~m}$ & 670438 & 22.68 & 90 & 19.43 & 0.86 \\
\hline & $2001 \sim 4000 \mathrm{~m}$ & 641690 & 21.71 & 68 & 14.68 & 0.68 \\
\hline & $>4001 \mathrm{~m}$ & 142846 & 4.83 & 8 & 1.72 & 0.36 \\
\hline
\end{tabular}


Table 2. Continued.

\begin{tabular}{|c|c|c|c|c|c|c|}
\hline \multirow[b]{2}{*}{ Factor } & \multirow[b]{2}{*}{ Class } & \multicolumn{2}{|c|}{$\begin{array}{l}\text { Total number of } \\
\text { pixels }\end{array}$} & \multicolumn{2}{|c|}{$\begin{array}{l}\text { Landslide occurrence } \\
\text { pixels }\end{array}$} & \multirow{2}{*}{$\begin{array}{c}\text { Frequency } \\
\text { ratio }\end{array}$} \\
\hline & & Number $^{a}$ & $\%$ & Number $^{b}$ & $\%$ & \\
\hline \multirow[t]{15}{*}{ Landuse } & Rubber & 674705 & 22.05 & 53 & 11.50 & 0.52 \\
\hline & Clear land & 75814 & 2.48 & 4 & 0.87 & 0.35 \\
\hline & Grass & 256259 & 8.37 & 14 & 3.04 & 0.36 \\
\hline & Wood & 27618 & 0.90 & 4 & 0.87 & 0.96 \\
\hline & Coconut & 88328 & 2.89 & 2 & 0.43 & 0.15 \\
\hline & Cultivated land & 774 & 0.03 & 1 & 0.22 & 8.58 \\
\hline & Wet paddy & 92852 & 3.03 & 0 & 0.00 & 0.00 \\
\hline & Horticulture & 12822 & 0.42 & 1 & 0.22 & 0.52 \\
\hline & Mangrove & 144562 & 4.72 & 13 & 2.82 & 0.60 \\
\hline & Primary forest & 1067028 & 34.87 & 347 & 75.27 & 2.16 \\
\hline & Rock & 10256 & 0.34 & 0 & 0.00 & 0.00 \\
\hline & Secondary forest & 498411 & 16.29 & 17 & 3.69 & 0.23 \\
\hline & Tin mine & 1876 & 0.06 & 5 & 1.08 & 17.69 \\
\hline & Oil palm & 2960 & 0.10 & 0 & 0.00 & 0.00 \\
\hline & Water body & 63 & 0.00 & 0 & 0.00 & 0.00 \\
\hline \multirow[t]{10}{*}{ NDVI } & $-73 \sim-18$ & 291092 & 10.05 & 33 & 7.13 & 0.71 \\
\hline & $-17 \sim 1$ & 300254 & 10.37 & 31 & 6.70 & 0.65 \\
\hline & $2 \sim 21$ & 297248 & 10.26 & 47 & 10.15 & 0.99 \\
\hline & $22 \sim 32$ & 315879 & 10.91 & 48 & 10.37 & 0.95 \\
\hline & $33 \sim 37$ & 358384 & 12.37 & 44 & 9.50 & 0.77 \\
\hline & $38 \sim 40$ & 322673 & 11.14 & 61 & 13.17 & 1.18 \\
\hline & $41 \sim 43$ & 373180 & 12.89 & 57 & 12.31 & 0.96 \\
\hline & $44 \sim 45$ & 226395 & 7.82 & 54 & 11.66 & 1.49 \\
\hline & $46 \sim 48$ & 242836 & 8.38 & 45 & 9.72 & 1.16 \\
\hline & $49 \sim 61$ & 168249 & 5.81 & 43 & 9.29 & 1.60 \\
\hline \multirow[t]{10}{*}{ Precipitation } & $2613 \sim 2651 \mathrm{~mm}$ & 310554 & 10.51 & 39 & 8.42 & 0.80 \\
\hline & $2652 \sim 2676 \mathrm{~mm}$ & 305133 & 10.33 & 13 & 2.81 & 0.27 \\
\hline & $2677 \sim 2695 \mathrm{~mm}$ & 298684 & 10.11 & 31 & 6.70 & 0.66 \\
\hline & $2696 \sim 2707 \mathrm{~mm}$ & 298405 & 10.10 & 24 & 5.18 & 0.51 \\
\hline & $2708 \sim 2718 \mathrm{~mm}$ & 292410 & 9.90 & 49 & 10.58 & 1.07 \\
\hline & $2719 \sim 2730 \mathrm{~mm}$ & 292990 & 9.92 & 44 & 9.50 & 0.96 \\
\hline & $2731 \sim 2742 \mathrm{~mm}$ & 293306 & 9.93 & 41 & 8.86 & 0.89 \\
\hline & $2743 \sim 2753 \mathrm{~mm}$ & 293819 & 9.94 & 73 & 15.77 & 1.59 \\
\hline & $2754 \sim 2763 \mathrm{~mm}$ & 293702 & 9.94 & 68 & 14.69 & 1.48 \\
\hline & $2764 \sim 2772 \mathrm{~mm}$ & 275779 & 9.33 & 81 & 17.49 & 1.87 \\
\hline
\end{tabular}

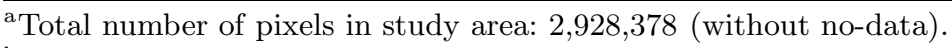

${ }^{\mathrm{b}}$ Number of landslide occurrence pixels: 463 .

probability of landslide occurrence, and for distances of $>1000 \mathrm{~m}$, the ratio was $<1$, indicating a low probability. As the distance from the lineament decreases, the fracture of the rock increases, and the degree of weathering increases resulting in greater chances of landslides. In the case of landuse (table 2), the landslide-occurrence values were higher in tin mine and cultivated land areas, and lower in grass, coconut and oil palm plantation areas. In the case of the vegetation index (table 2), for NDVI values below 37, the frequency ratio was $<1$, which indicates a low landslide-occurrence probability, and for NDVI values above 37 , the frequency ratio was $>1$, indicating a high landslideoccurrence probability. However, for NDVI value between 41 and 43 the frequency ratio was 0.96 


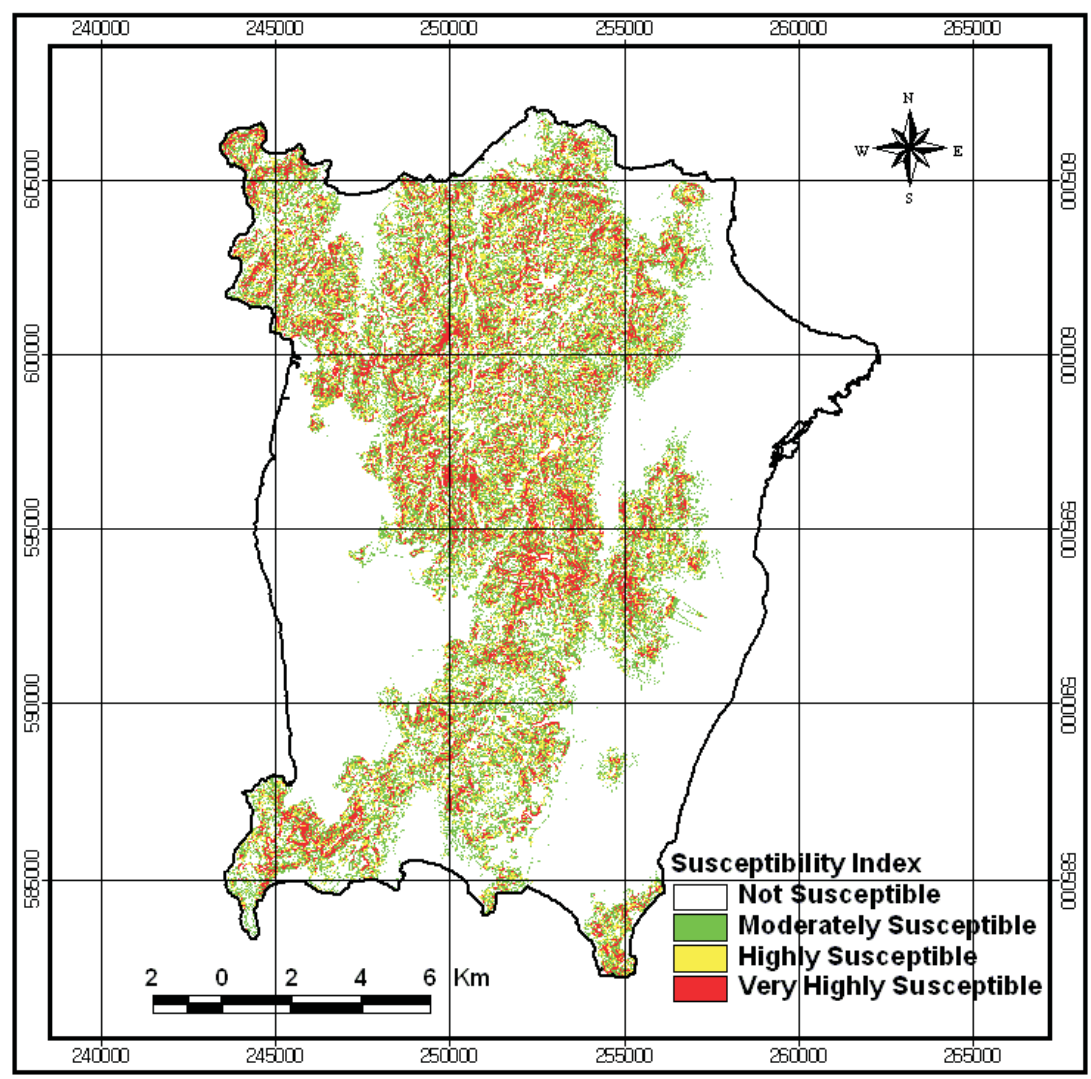

Figure 2. Landslide susceptibility map based on frequency ratio model.

which is almost equal to 1 . This result means that the landslide probability increases with the vegetation index value. This could be due to more vegetation seen along structurally weaker zones. For soil class (table 2), it was found that the frequency ratio was higher for Rengam-bukit temiang association (2.07) and steep land (1.41), and was lower $(0.0-0.22)$ in other series. This result indicates that the landslide probability increases with the steep land. In the case of rainfall precipitation (table 2), for a precipitation amount below $2707 \mathrm{~mm}$, the frequency ratio was $<1$, which indicates a low landslide-occurrence probability, and for a precipitation amount above $2707 \mathrm{~mm}$, the frequency ratio was $>1$, indicating a high landslide-occurrence probability. However, for precipitation value between 2719 and $2742 \mathrm{~mm}$, the frequency ratio was 0.96 and 0.89 which is almost equal to 1 . This could be due to the prolonged spell of rainfall during monsoon season that could have led to the high landslide-occurrence probability.

\section{Landslide susceptibility analysis}

Using the frequency ratio model, the spatial relationship between a landslide location and each landslide-related factor was derived. For landslide susceptibility analysis, the calculated and extracted factors were converted to a $10 \times 10 \mathrm{~m}^{2}$ grid using ArcInfo software. In the study area, the total number of pixels was $2,928,378$, and the number of landslide-occurrence pixels was 463. The correlation of coefficients was calculated from the analysis of the relationship between the landslides and the relevant factors. The rating of each factor's type or range was assigned from the relationship between a landslide and each factor's type or range, that is, the ratio of the number of pixels where landslides occurred to the total number of pixels as shown in table 2. The landslide susceptibility index (LSI) was calculated by summation of each factor's ratings using equation (1):

$$
L S I=\Sigma F r
$$

(where $F r$ is the rating of each factor's type or range).

After calculations using equation (1), the LSI had a minimum value of 2.83 , and a maximum value of 31.3 , with an average value of 9.73 and a standard deviation of 2.96 . The other cases are given in table 2 . Figure 2 shows the landslide susceptibility map generated based on the frequency ratio model.

The susceptibility map was verified using existing landslide location. For the verification, the area under the curve method (Lee et al 2004a) was used. 


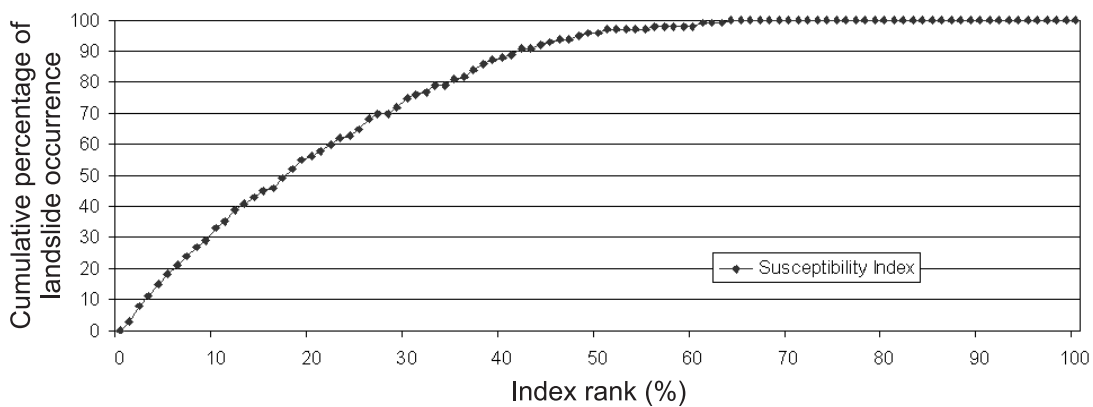

Figure 3. Cumulative frequency diagram showing landslide susceptibility index rank occurring in cumulative per cent of landslide occurrence.

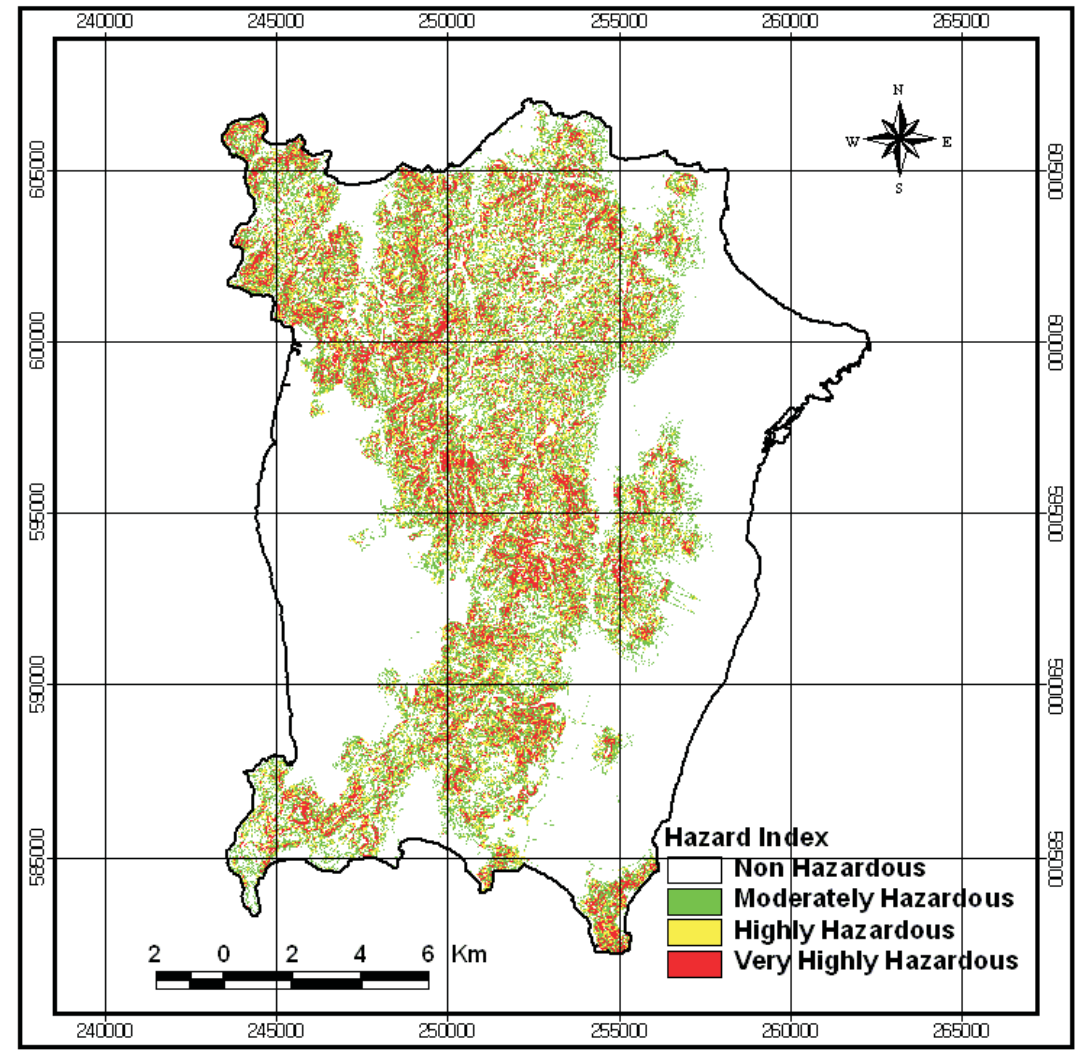

Figure 4. Landslide hazard map of the study area.

To obtain the rate curves, the calculated landslide susceptibility index values of all pixels in the study area were sorted in descending order. Then, the ordered pixel values were divided into 100 classes, with accumulated $1 \%$ intervals. The rate curves explain how well the method and factors predict landslides. The area under a curve can be used to assess the prediction accuracy qualitatively. Total area $=1$ denotes perfect prediction accuracy. The rate verification results appear as graph in figure 3 . For example, $10 \%$ of the study area where the landslide susceptibility index had a higher rank could explain $33 \%$ of all the landslides. In addition,
$30 \%$ of the study area where the landslide susceptibility index had a higher rank could explain $75 \%$ of the landslides. In the case of the frequency ratio model used for susceptibility map, the area ratio was 0.8003 and the prediction accuracy was 80.03\%. The Global Positioning System data for landslide locations has been collected for various parts of Penang Island in the month of July and October. Twenty one active landslides have been recorded and used to verify the model output. The result shows that there is a fair agreement between the prediction accuracy and the occurrence of landslides in a particular area. 


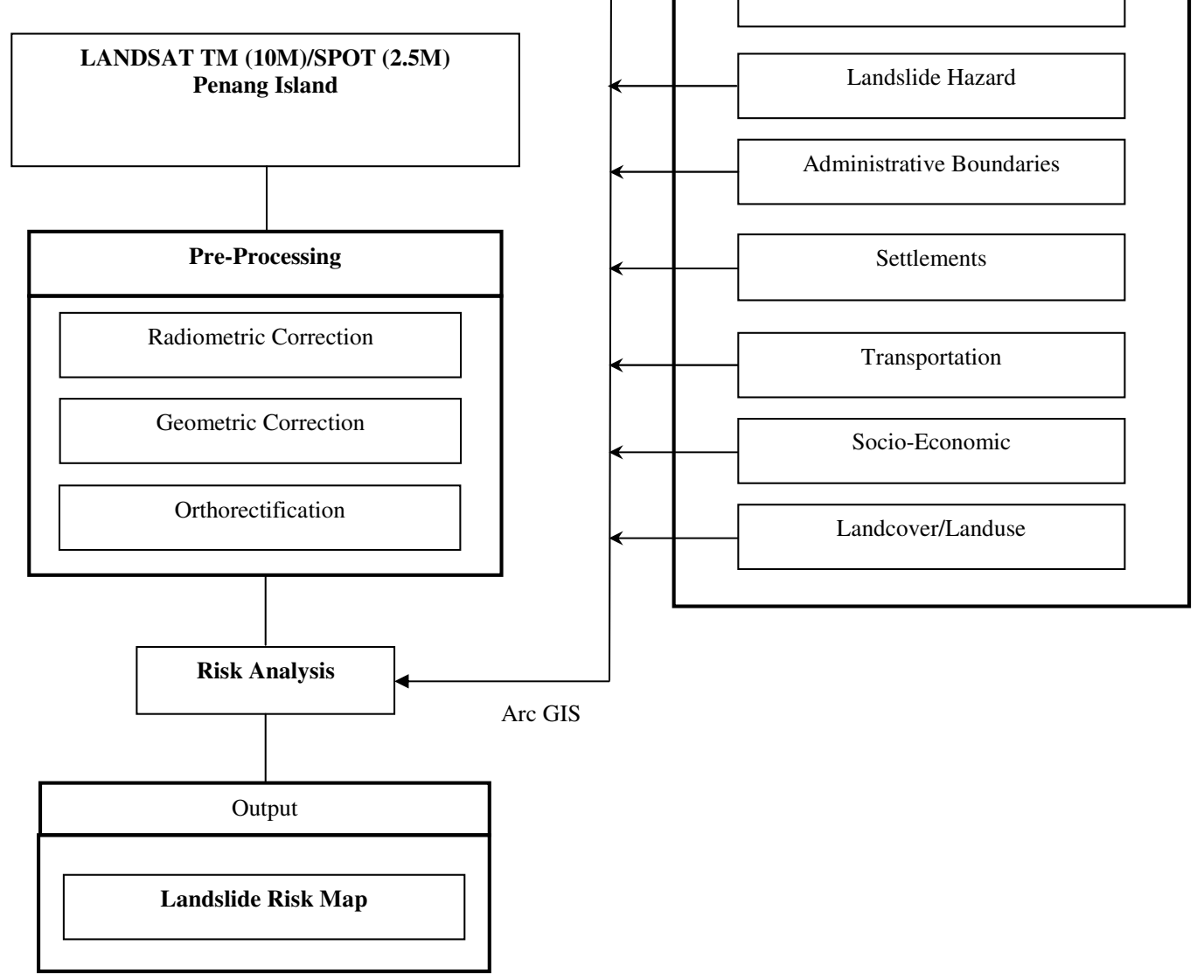

Figure 5. Flow chart for the methodology of landslide risk analysis.

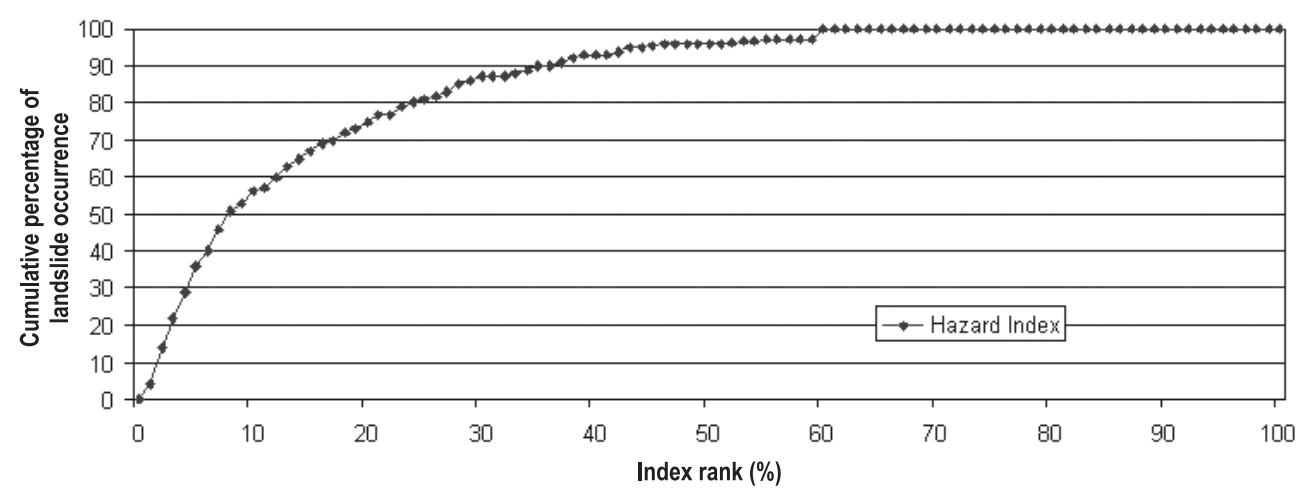

Figure 6. Cumulative frequency diagram showing landslide hazard index rank occurring in cumulative per cent of landslide occurrence.

\section{Landslide hazard and risk analysis}

In the study area, firstly the landslide susceptibility map was produced based on the frequency ratio model using map overlaying techniques. Then the landslide susceptibility map was overlaid on the precipitation map of the study area to produce the landslide hazard map (figure 4). Figure 5 shows the flow chart of the methodology adopted for risk analysis. In the hazard map, the potential event and its probability of occurrence were combined. The hazard categories are expressed as 


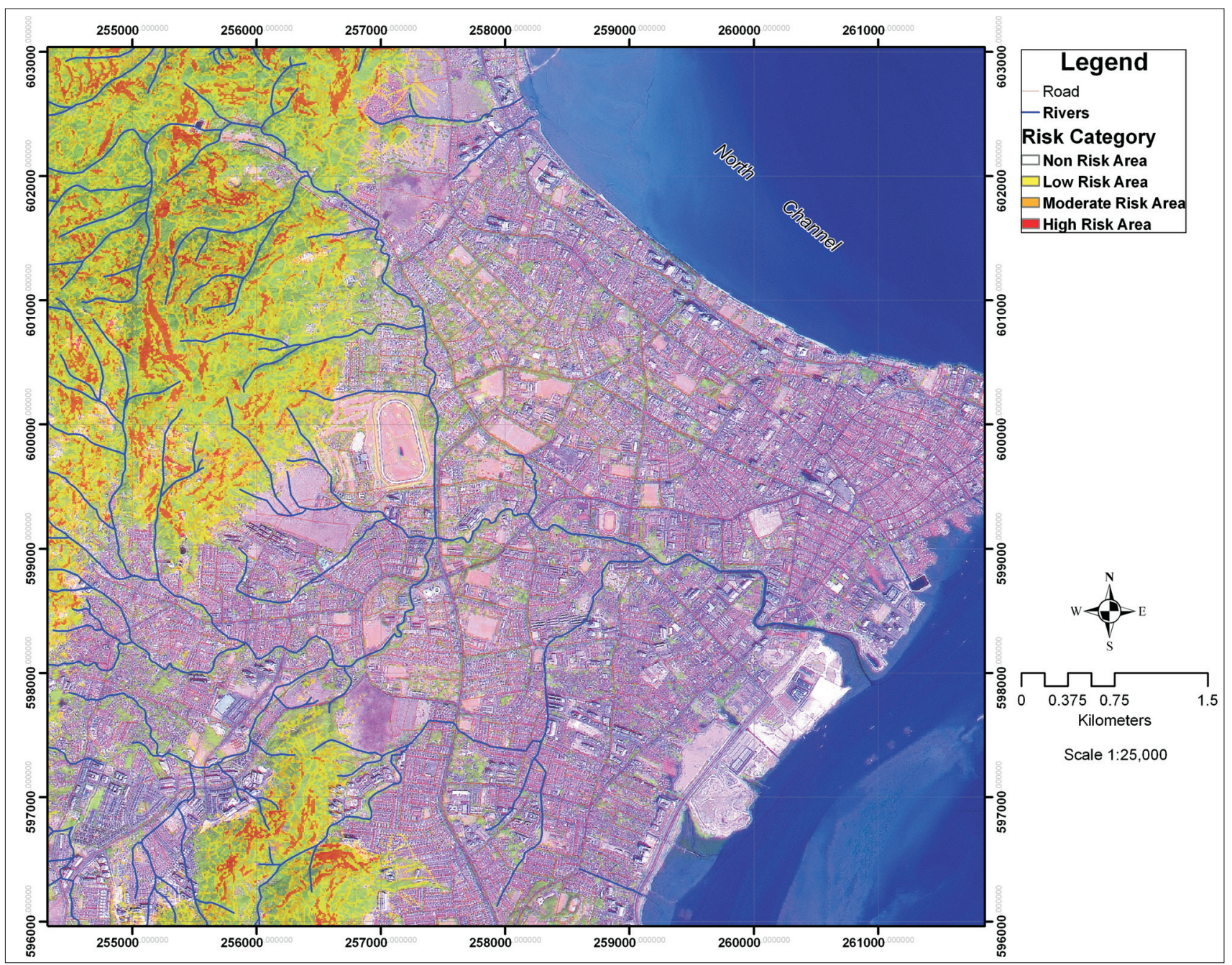

Figure 7. Landslide risk map of the northeastern part of the study area.

probability in qualitative forms (e.g., none, low, moderate, high). The accuracy of the hazard map was the area ratio of 0.8641 and the prediction accuracy of $86.41 \%$ (figure 6). Overall, the case of hazard map showed a higher accuracy than the susceptibility map.

In the landslide hazard map a particular surface area subjected to the same hazard can face a variety of consequences, depending on landuse. Therefore, the hazard map was overlaid on damageable objects maps such as transportation network, settlement and facility centers. Figure 7 shows the landslide risk map of the northeastern part of the study area. It has been observed that, many settlements have been built up on high landslide risk areas where the probability of occurrence of landslide is very high. Those high risk areas need to be brought to the notice of the public so that people can realize the possibility of future landslides. This could save their life and their property.

\section{Discussion and conclusions}

Landslide, like other natural hazards such as flood, earthquake and avalanche is often difficult to predict. However, landslide risk can be systematically assessed and managed. Hazard and risk maps are usually the end product of landslide mapping but they are the basis for decision making. These decisions are usually in the form of technical countermeasures, regulatory management, or combinations of the two. Classic examples of regulatory management are zoning maps which, for instance, exclude some landslide-prone areas from habitation.

Landslide susceptibility maps have been constructed using the relationship between each landslide and causative factors. In this study, a probabilistic approach to estimate areas susceptible to landslides using GIS and remote sensing is presented. The landslide susceptibility map was overlaid on the precipitation map to produce the 
landslide hazard map. The verification result of frequency ratio model, showed $80.03 \%$ and $86.41 \%$ prediction accuracy in susceptibility and hazard maps respectively. Therefore, using precipitation data, the influence of factors on the landslide susceptibility map can improve the prediction accuracy $6.38 \%$ in the landslide hazard map.

Risk analysis was performed for the study area. The landslide hazard map was overlaid on the settlement map to produce the landslide risk map. These results can be used as basic data to assist slope management and landuse planning. The methods used in the study are also valid for generalized planning and assessment purposes, although they may be less useful on the site-specific scale, where local geological and geographic heterogeneities may prevail. For the model to be more generally applied, more landslide data are needed.

\section{Acknowledgements}

Authors would like to thank the Malaysian Center for Remote Sensing for providing various remote sensing data sets. Thanks to Jasmi Ab Taib for providing historical landslide location data. Thanks are also due to C $\mathrm{P}$ Johnson, Manish Kale and $\mathrm{T} \mathrm{N}$ Singh for their constructive reviews of the manuscript.

\section{References}

Atkinson P M and Massari R 1998 Generalized linear modeling of susceptibility to landsliding in the central Apennines, Italy; Computer \&5 Geosciences 24 373-385.

Baeza C and Corominas J 2001 Assessment of shallow landslide susceptibility by means of multivariate statistical techniques; Earth Surface Processes and Landforms 26 $1251-1263$.

Carro M, Amicis M, Luzi L and Marzorati S 2003 The application of predictive modeling techniques to landslides induced by earthquakes, the case study of the 26 September 1997 Umbria-Marche earthquake (Italy); Engineering Geology 69 139-159.

Christian J T, Ladd C C and Baecher G B 1992 Reliability and probability in stability; In: Stability and Performance of Slope and Embankments-II; Geotechnical Special Publication No. 3; Proc. ASCE Specialty Conference, Berkeley 1071-1111.

Clerici A, Perego S, Tellini C and Vescovi P 2002 A procedure for landslide susceptibility zonation by the conditional analysis method; Geomorphology 48 349-364.

Dai F C, Lee C F, Li J and Xu Z W 2001 Assessment of landslide susceptibility on the natural terrain of Lantau Island, Hong Kong; Environmental Geology 40 381-391.

Dai F C and Lee C F 2002 Landslide characteristics and slope instability modeling using GIS; Lantau Island, Hong Kong; Geomorphology 42 213-228.

Donati L and Turrini M C 2002 An objective method to rank the importance of the factors predisposing to landslides with the GIS methodology, application to an area of the Apennines (Valnerina; Perugia, Italy); Engineering Geology 63 277-289.
Einstein H H 1988 Landslide risk assessment procedure; Proceedings of the Fifth International Symposium on Landslides 1075-1090.

Ercanoglu M and Gokceoglu C 2002 Assessment of landslide susceptibility for a landslide-prone area (north of Yenice, NW Turkey) by fuzzy approach; Environmental Geology 41 720-730.

Fell R 1994 Landsldie risk assessment and acceptable risk; Canadian Geotechnical Journal 31 261-272.

Gokceoglu C, Sonmez H and Ercanoglu M 2000 Discontinuity controlled probabilistic slope failure risk maps of the Altindag (settlement) region in Turkey; Engineering Geology 55 277-296.

Guzzetti F, Carrarra A, Cardinali M and Reichenbach P 1999 Landslide hazard evaluation: a review of current techniques and their application in a multi-scale study, Central Italy; Geomorphology 31 181-216.

Jibson W R, Edwin L H and John A M 2000 A method for producing digital probabilistic seismic landslide hazard maps; Engineering Geology 58 271-289.

Lee S and Min K 2001 Statistical analysis of landslide susceptibility at Yongin, Korea; Environmental Geology $\mathbf{4 0}$ 1095-1113.

Lee S, Chwae U and Min K 2002a Landslide susceptibility mapping by correlation between topography and geological structure: the Janghung area, Korea; Geomorphology 46 49-162.

Lee S, Choi J and Min K 2002b Landslide susceptibility analysis and verification using the Bayesian probability model; Environmental Geology 43 120-131.

Lee S, Ryu J H, Min K and Won J S 2003a Landslide Susceptibility Analysis using GIS and artificial neural network; Earth Surface Processes and Landforms 27 1361-1376.

Lee S, Ryu J H, Lee M J and Won J S 2003b Landslide susceptibility analysis using artificial neural network at Boun, Korea; Environmental Geology 44 $820-833$.

Lee S and Choi U 2003c Development of GIS-based geological hazard information system and its application for landslide analysis in Korea; Geoscience Journal 7 243-252.

Lee S, Ryu J H, Won J S and Park H J 2004a Determination and application of the weights for landslide susceptibility mapping using an artificial neural network; Engineering Geology 71 289-302.

Lee S, Choi J and Min K 2004b Probabilistic landslide hazard mapping using GIS and remote sensing data at Boun, Korea; International Journal of Remote Sensing 25 2037-2052.

Luzi L, Pergalani F and Terlien M T J 2000 Slope vulnerability to earthquakes at sub-regional scale, using probabilistic techniques and geographic information systems; Engineering Geology 58 313-336.

Ohlmacher G C and Davis J C 2003 Using multiple logistic regression and GIS technology to predict landslide hazard in northeast Kansa, USA; Engineering Geology 69 331-343.

Parise M and Jibson W R 2000 A seismic landslide susceptibility rating of geologic units based on analysis of characteristics of landslides triggered by the 17 January, 1994 Northridge, California earthquake; Engineering Geology 58 251-270.

Pistocchi A, Luzi L and Napolitano P 2000 The use of predictive modeling techniques for optimal exploitation of spatial databases: a case study in landslide hazard mapping with expert system-like methods; Environmental Geology 41 765-775.

Rautelal P and Lakhera R C 2000 Landslide risk analysis between Giri and Tons Rivers in Himachal Himalaya 
(India); International Journal of Applied Earth Observation and Geoinformation 2 153-160.

Rece A and Capolongo D 2002 Probabilistic modeling of uncertainties in earthquake-induced landslide hazard assessment; Computers \& Geosciences 28 735-749.

Romeo R 2000 Seismically induced landslide displacements: a predictive model; Engineering Geology 58 337-351.

Rowbotham D and Dudycha D N 1998 GIS modeling of slope stability in Phewa Tal watershed, Nepal; Geomorphology 26 151-170.

Shou K J and Wang C F 2003 Analysis of the Chiufengershan landslide triggered by the 1999 Chi-Chi earthquake in Taiwan; Engineering Geology 68 237-250.

Temesgen B, Mohammed M U and Korme T 2001 Natural hazard assessment using GIS and remote sensing methods, with particular reference to the landslides in the
Wondogenet area, Ethiopia; Physics and Chemistry of the Earth, Part C: Solar, Terrestrial and Planetary Science 26 665-675.

Varne D J 1984 Landslide hazard zonation: A review of principles and practice; Natural Hazards $\mathbf{3} 63$.

Whitman R V 1984 Evaluating calculated risk in geotechnical engineering; ASCE Journal of Geotechnical Engineering 110 145-188.

Zhou C H, Lee C F, Li J and Xu Z W 2002 On the spatial relationship between landslides and causative factors on Lantau Island, Hong Kong; Geomorphology 43 197-207.

Zhou G, Esaki T, Mitani Y, Xie M and Mori J 2003 Spatial probabilistic modeling of slope failure using an integrated GIS Monte Carlo simulation approach; Engineering Geology 68 373-386. 